\title{
Pengaruh Penggunaan Roti Afkir sebagai Pengganti Bekatul dan Gaplek dalam Konsentrat Sapi Perah terhadap Produksi Susu
}

\author{
(The Effect of Using Leftover Bread as a Subtitute of Rice Bran and Cassava Meal in \\ Concentrate feed of Dairy Cattle to Milk Production)
}

\author{
Winarti E \\ Balai Pengkajian Teknologi Pertanian Yogyakarta, Jl. Stadion Maguwoharjo No. 22, Sleman, Yogyakarta \\ ernawinarti@gmail.com
}

\begin{abstract}
The aim of this study was to determine the effect of the substitution of the rice bran and cassava meal by leftover bread in the diet of dairy cattle on milk production. The design of the experiment used was Latin Square Design. Five dairy cows were used in this trial, with five treatments of feed. Treatment (P1) the used of leftover bread as much as 30\%, (P2) used leftover bread as much as $22.5 \%$, (P3) the use of leftover bread as much as $15 \%$, (P4) the use of leftover bread by $7.5 \%$ and (P5) use leftover bread by $0 \%$. The feed was given for four weeks, then the feed intake and milk production were observed. Data were analyzed by analysis of variance, if there were differences continued with Duncan Range Test. Results showed that the replacement of the rice bran and cassava meal up to $30 \%$ had no effect on feed intake and milk production. It can be concluded that the use of leftover bread to substitute rice bran and cassava can be done up to $30 \%$.
\end{abstract}

Key Words: Dairy Cattle, Leftover Bread, Milk Production

\begin{abstract}
ABSTRAK
Penelitian bertujuan untuk mengetahui pengaruh penggantian bekatul dan gaplek dengan roti afkir dalam pakan sapi perah terhadap produksi susu. Rancangan percoban yang digunakan adalah rancangan bujur sangkar latin. Lima ekor sapi perah digunakan dalam percobaan ini dengan 5 perlakuan pakan. Perlakuan (P1) penggunaan roti afkir sebanyak 30\%, (P2) penggunaan roti afkir sebanyak 22,5\%, (P3) penggunaan roti afkir sebanyak 15\%, (P4) penggunaan roti afkir sebanyak $7,5 \%$ dan (P5) penggunaan roti afkir 0\%. Pakan diberikan selama empat minggu dan dilakukan pengamatan terhadap konsumsi pakan dan produksi susu. Data dianalisis dengan analisis Sidik Ragam, jika ada perbedaan dilanjutkan dengan uji Jarak Duncan. Hasi penelitian menunjukkan bahwa penggantian bekatul dan onggok dengan roti afkir hingga $30 \%$ tidak berpengaruh terhadap konsumsi pakan dan produksi susu. Dapat disimpulkan bahwa penggunaan roti afkir sebagai pengganti bekatul dan onggok bisa dilakukan hingga 30\%.
\end{abstract}

Kata Kunci: Sapi Perah, Roti Afkir, Produksi Susu

\section{PENDAHULUAN}

Susu sebagai salah satu produk peternakan merupakan sumber protein hewani yang semakin dibutuhkan dalam meningkatkan kualitas hidup masyarakat. Sebagai upaya untuk memenuhi kebutuhan susu tersebut dilakukan peningkatan populasi, produksi dan produktifivitas sapi perah. Populasi sapi perah di Daerah Istimewa Yogyakarta pada Tahun 2014 berjumlah 3.990 ekor dan pada tahun 2015 berjumlah 4.044 ekor atau naik sekitar 1,35\% (BPS 2016). Lebih dari 90\% sapi perah berada di Kabupaten Sleman dan sebagian besar merupakan peternakan rakyat yang dikelola dalam skala kecil. Permasalahan yang dihadapi dalam usaha sapi perah terbagi dalam tiga sektor yaitu hulu, tengah dan hilir. Permasalahan di sektor hulu antara lain produktivitas masih rendah, kurangnya 
ketersediaan bibit sapi perah, biaya pakan tinggi, skala pemilikan kecil dan mutu sumberdaya manusia masih rendah. Permasalahan di sektor tengah meliputi teknis budidaya dan sistem recording rendah, ketersediaan lahan untuk produksi pakan menurun, konversi lahan pertanian ke non pertanian, modal usaha dari perbankan masih rendah serta kerjasama lintas sektoral belum terpadu. Permasalahan di sektor hilir antara lain harga susu segar dan konsumen masih rendah serta harga jual pedet/sapi perah tidak stabil (Mandaka \& Hutagaol 2005).

Pakan merupakan faktor penting dalam usaha sapi perah. Jumlah dan kualitas pakan yang diberikan sangat berpengaruh terhadap produksi susu. Untuk mendapatkan produksi susu yang optimal, selain diberi pakan hijauan juga harus disediakan konsentrat. Menurut Sudono et al. (2003), faktor yang mempengaruhi kualitas dan kuantitas susu sapi perah adalah bangsa sapi, lama bunting, masa laktasi, besar sapi, estrus atau berahi, umur sapi, selang beranak, masa kering, frekuensi pemerahan, dan tata laksana pemberian pakan.

Energi dan protein merupakan dua nutrien pokok yang sangat dibutuhkan oleh ternak. Sumber energi yang biasa digunakan dalam menyusun konsentrat diantaranya adalah jagung, katul, polard, gaplek dan onggok. Salah satu sumber energi yang bisa digunakan adalah roti afkir. Roti afkir adalah roti yang telah lewat batas waktu konsumsi sehingga tidak layak dikonsumsi manusia. Roti afkir mengandung energi cukup tinggi, karena roti dibuat dengan bahan dasar terigu. Harga roti afkir juga relatif lebih murah dibanding bekatul maupun gaplek

Menurut Agus et al. (2005) kadar protein roti afkir 5,1\% dan bahan organik 91,4\%, sedangkan menurut Winarti \& Supriadi (2014) kandungan protein roti afkir 6,1\%, lemak kasar 7,5\% dan serat kasar 4,7\%. Chalimi et al. (2010) menyatakan bahwa kecernaan energi roti afkir lebih baik dari pada dedak padi dan layak diberikan sebagai pakan untuk sapi PO. Kandungan protein roti afkir 12,63\% dan BETN 78,42\% (Diyatmoko et al. 2010), lebih lanjut dikatakan bahwa roti afkir juga lebih baik dalam memproduksi protein mikroba dibanding dedak padi. Protein asal mikroba rumen mempunyai kontribusi $40-80 \%$ terhadap pemenuhan asam amino/nitrogen ternak sapi induk semangnya dan merupakan nutrien berkualitas tinggi (Sniffen \& Robinson 1987). Penggunaan roti afkir dalam konsentrat sapi perah perlu dikaji untuk mengetahui pegaruhnya terhadap produksi susu. Tujuan pengkajian ini adalah untuk mengetahui penggunaan roti afkir sebagai pengganti bekatul dan gaplek dalam konsentrat terhadap produksi susu sapi perah.

\section{MATERI DAN METODE}

Pengkajian dilaksanakan di UPTD Balai Pengembangan Bibit, Pakan Ternak dan Diagnostik Kehewanan (BPBPTDK), Ngipiksari, Hargobinangun, Pakem, Sleman, Daerah Istimewa Yogyakarta pada bulan April s.d. September 2016. Lima ekor sapi perah digunakan dalam percobaan ini, dengan lima perlakuan pakan. Susunan ransum masingmasing perlakuan disajikan pada Tabel 1. Bahan pakan ditimbang sesuai dengan proporsi yang telah ditetapkan. Bahan pakan gaplek, menir kedelai dan roti afkir digiling, selanjutnya semua bahan pakan dicampur. Roti afkir yang digunakan diantaranya bakpia dengan isi kacang hjau dan cokelat. Masing-masing pakan perlakuan diberikan selama empat minggu. Rancangan percoban yang digunakan adalah Rancangan Bujur Sangkar Latin (Latin Square Design).

\section{Pemberian pakan dan air minum}

Pakan konsentrat diberikan $6 \mathrm{~kg}$ per hari per ekor, diberikan dua kali yaitu pada pukul $03.00 \mathrm{WIB}$ dan $11.30 \mathrm{WIB}$ masing masing $3 \mathrm{~kg}$. Hijauan yang diberikan adalah rumput 
King grass, diberikan dua kali sehari pada pagi pukul 09.00 WIB dan siang pukul 14.00 WIB. Air minum diberikan secara ad libitum.

Tabel 1. Bahan penyusun konsentrat

\begin{tabular}{lccccc}
\hline \multirow{2}{*}{ Bahan pakan } & \multicolumn{5}{c}{ Ransum } \\
\cline { 2 - 6 } & P1 & P2 & P3 & P4 & P5 \\
\cline { 2 - 6 } Katul & 0 & 3,75 & 7,5 & 11,25 & 15 \\
Gaplek & 0 & 3,75 & 7,5 & 11,25 & 15 \\
Roti afkir & 30 & 22,5 & 15 & 7,5 & 0 \\
Bungkil kopra & 22 & 22 & 22 & 22 & 22 \\
Bungkil sawit & 20 & 20 & 20 & 20 & 20 \\
Menir kedelai & 13 & 13 & 13 & 13 & 13 \\
Kulit kacang & 10 & 10 & 10 & 10 & 10 \\
Tetes & 3 & 3 & 3 & 3 & 3 \\
Garam & 1 & 1 & 1 & 1 & 1 \\
mineral & 1 & 1 & 1 & 1 & 1 \\
\hline Total & 100 & 100 & 100 & 100 & 100 \\
\hline Serat Kasar & 10,31 & 10,53 & 10,75 & 10,96 & 11,18 \\
Lemak Kasar & 7,27 & 7,18 & 7,14 & 7,08 & 7,01 \\
Protein kasar & 16,83 & 16,55 & 16,33 & 16,08 & 15,83 \\
BETN & 58,56 & 58,29 & 58,40 & 58,32 & 58,24 \\
\hline
\end{tabular}

\section{Pengumpulan data}

Pengamatan dilakukan terhadap konsumsi pakan dan produksi susu. Susu diperah 2 kali sehari pagi hari pukul 07.00 WIB dan sore Pukul 15.00 WIB. Susu yang dihasilkan diukur volumenya dengan bejana pengukur volume. Data dianalisis dengan Analisis Sidik ragam, jika ada perbedaan dilanjutkan dengan Uji Jarak Duncan.

\section{HASIL DAN PEMBAHASAN}

\section{Konsumsi pakan}

Konsumsi hijauan segar dihitung dari banyaknya hijauan yang diberikan dalam sehari dikurangi hijauan yang tersisa. Konsumsi hijauan segar disajikan pada Tabel 2. Rerata konsumsi hijauan segar perlakuan P1, P2, P3, P4 dan P5 berturut-turut adalah 39,17 kg, $39,00 \mathrm{~kg}, 39,23 \mathrm{~kg}, 39,47 \mathrm{~kg}$ dan 39,26 kg. Hasil analisa sidik ragam menunjukkan bahwa konsumsi hijauan tidak berbeda nyata antar perlakuan. Pemberian konsentrat sebanyak 6 $\mathrm{kg} / \mathrm{ekor} / \mathrm{hari}$ pada semua perlakuan tidak ada sisa, sehingga konsumsi konsentrat adalah sama yaitu $6 \mathrm{~kg} / \mathrm{ekor}$. Hal ini menunjukkan bahwa penggantian bekatul dan gaplek dengan roti afkir tidak menurunkan palatabilitas.

Konsumsi bahan kering merupakan jumlah konsumsi bahan kering konsentrat dan bahan kering rumput segar. Konsumsi bahan kering harian perlakuan P1, P2, P3, P4 dan P5 berturut-turut adalah 13,115 kg, 13,080 kg, 13,127 kg, 13,174 kg dan 13,132 kg (Tabel 2). Hasil analisis Sidik Ragam menunjukkan bahwa konsumsi bahan kering tidak ada 
perbedaan yang nyata antar perlakuan. Konsumsi bahan kering dipengaruhi oleh palatabilitas, kecepatan alir pakan dalam saluran pencernaan, ukuran partikel pakan dan kecernaan pakan (Arora 1989).

Nilai efisiensi ransum adalah banyaknya produksi susu untuk setiap $\mathrm{kg}$ bahan kering ransum yang dikonsumsi. Nilai efisiensi ransum perlakuan $\mathrm{P} 1$ sebesar 82,16\% yang berarti setiap konsumsi $1 \mathrm{~kg}$ bahan kering menghasilkan susu 0,8216 liter. Nilai efisiensi ransum antar perlakuan secara statistik tidak berbeda nyata. Nilai efisiensi ransum yang tinggi akan berdampak pada keuntungan yang diperoleh peternak, apalagi kalau harga konsentrat lebih rendah.

Table 2. Rata-rata konsumsi pakan, produksi susu dan nilai efisiensi pakan

\begin{tabular}{lccccc}
\hline \multirow{2}{*}{ Uraian } & \multicolumn{5}{c}{ Perlakuan } \\
\cline { 2 - 6 } & P1 & P2 & P3 & P4 & P5 \\
\hline Konsumsi rumput (kg/hari) & 39,17 & 39,00 & 39,23 & 39,47 & 39,26 \\
Konsumsi konsentrat (kg/hari) & 6,00 & 6,00 & 6,00 & 6,00 & 6,00 \\
Konsumsi Bahan kering (kg/hari) & 13,12 & 13,09 & 13,13 & 13,17 & 13,13 \\
Produksi susu (liter/hari) & 10,78 & 9,70 & 10,06 & 9,19 & 10,21 \\
Nilai efisiensi pakan (\%) & 82,16 & 74,10 & 76,62 & 69,78 & 77,76 \\
\hline
\end{tabular}

\section{Produksi susu}

Rata-rata produksi susu harian sapi perah pada perlakuan P1, P2, P3, P4 dan P5 berturut-turut adalah 10,78; 9,70;10,06; 9,19; dan 10,21 1/ekor/hari (Tabel 2). Hasil Analisis Sidik Ragam tidak menunjukkan perbedaan yang nyata $(\mathrm{P}>0,05)$ antar perlakuan. Hal ini menunjukkan bahwa penggantian sumber energi bekatul dan gaplek dengan roti afkir hingga 30\% dapat dilakukan tanpa mengganggu produksi susu. Kandungan protein pakan perlakuan belum mampu meningkatkan produksi susu secara nyata. Produksi susu selama penelitian relatif sama dengan produksi susu Nasional yaitu 8-10 1/ekor/hari (Prihatin 2008).

\section{KESIMPULAN}

Pemanfaatan roti afkir dapat digunakan sebagai pengganti bekatul dan gaplek. Penggunaan roti afkir sampai $30 \%$ dalam ransum konsentrat tidak memberikan pengaruh yang signifikan pada produksi susu.

\section{UCAPAN TERIMA KASIH}

Penulis mengucapkan terima kasih kepada Kepala UPTD Balai Pengembangan Bibit, Pakan Ternak dan Diagnostik Kehewanan DIY yang telah penyediaan fasilitas dan Ir. Sugiharto atas bantuan tehnis selama penelitian berlangsung.

\section{DAFTAR PUSTAKA}

Agus A, Suwignyo B, Utomo R. 2005. Penggunaan complete feed berbasis jerami padi fermentasi pada sapi Australian commercial cross terhadap konsumsi nutrien dan pertambahan bobot badan harian. Buletin Peternakan. hlm 1-9 
Arora SP. 1989. Pencernaan mikroba pada ruminansia. Gadjah Mada University Press. Yogyakarta

BPS. 2016. Badan Pusat Statistik Propinsi Daerah Istimewa Yogyakarta.

Chalimi K, Rochim A, Purbowati E, Soedarsono, Rianto E, Purnomoadi A. 2010. Kelayakan roti sisa pasar sebagai pakan alternatif berdasar pemanfaatan kecernaan energi dan parameter darah pada sapi Peranakan Ongole. Prosiding Semnas Teknologi Peternakan dan Veteriner. Bogor, 13-14 Agustus 2009. Pusat Penelitian dan Pengembangan Peternakan. hlm. 100-106

Diyatmoko A, Fitrianto MRH, Purbowati E, Arifin A, Purnomoadi A. 2010. Pemanfaatan protein pakan dan produksi protein mikroba pada sapi Peranakan Ongole (PO) yang diberi pakan sisa pasar sebagai pengganti dedak padi. Prosiding Semnas Teknologi Peternakan dan Veteriner. Bogor, 13-14 Agustus 2009. Pusat Penelitian dan Pengembangan Peternakan. hlm. . $220-225$

Mandaka S, Hutagaol MP. 2005. Analisis fungsi keuntungan, efisiensi ekonomi dan kemungkinan skema kredit bagi pengembangan skala usaha peternakan sapi perah rakyat di Kelurahan Kebon Pedes, Kota Bogor. J Agro Ekonomi 23: 191-208.

Prihatin OD. 2008. Performa reproduksi sapi FH betina di peternakan rakyat KPSBU dan BPPTSP Cikole Lembang (Skripsi). Institut Pertanian Bogor.

Sniffen CJ, Robinson PH. 1987. Microbial growth and flow as influenced by dietary manipulations. J. Dairy Sci. 70:425-431

Sudono A, Rosdiana RF, Setiawan BS. 2003. Beternak Sapi Perah Secara Intensif. Agromedia Pustaka. Jakarta

Winarti E, Supriadi. 2104. Pengaruh penggantian jagung dengan roti afkir dalam pakan komplit terhadap pertambahan bobot badan sapi Peranakan Ongole. Prosiding Semnas Teknologi Peternakan dan Veteriner. Malang, 12-14 Agustus 2014. Pusat Penelitian dan Pengembangan Peternakan. hlm. $178-183$.

\section{DISKUSI}

\section{Pertanyaan}

Apakah ada standar roti afkir yg digunakan? Apakah ada perbedaan kandungan karena isi roti yg berbeda (kacang hijau, cokelat dan lain-lain)?

\section{Jawaban}

Tidak ada standar, yang telah digunakan jamur pada roti belum terlalu banyak. 